\title{
Efficacy of Solarization and Cabbage Amendment for the Control of Phytophthora spp. in North Florida
}

\author{
L. Coelho, Postdoctoral Associate, Plant Pathology Department, University of Florida, Gainesville 32611; D. O. \\ Chellemi, Research Plant Pathologist, U.S. Department of Agriculture, Agricultural Research Service, 2199 S. \\ Rock Road, Fort Pierce, FL 34945; and D. J. Mitchell, Professor, Plant Pathology Department, University of Flor- \\ ida, Gainesville 32611
}

\begin{abstract}
Coelho, L., Chellemi, D. O., and Mitchell, D. J. 1999. Efficacy of solarization and cabbage amendment for the control of Phytophthora spp. in North Florida. Plant Dis. 83:293-299.

The effects of soil solarization with or without cabbage leaf amendments on the survival of Phytophthora spp. were evaluated in several North Florida soils. Soil temperature under solarization treatments reached a maximum of $47^{\circ} \mathrm{C}$ at a $10-\mathrm{cm}$ depth, but only $41^{\circ} \mathrm{C}$ at $25 \mathrm{~cm}$. Solarization with a clear, gas-impermeable film was as effective as methyl bromide in reducing populations of $P$. nicotianae at a 10-cm depth but had no effect on populations at a depth of 25 $\mathrm{cm}$. Populations of $P$. capsici after solarization with either a clear, low-density polyethylene or a clear, gas-impermeable film were similar to methyl bromide treatment at the $10-\mathrm{cm}$ depth, while at the $25-\mathrm{cm}$ depth, no reduction in populations was observed. Incorporation of cabbage into the soil at a rate of 6.6 to $8.9 \mathrm{~kg} / \mathrm{m}^{2}$ did not enhance the effectiveness of solarization in reducing populations of either Phytophthora sp.
\end{abstract}

Additional keywords: Brassica oleracea var. capitata, chloropicrin, nonchemical control, organic amendment

Phytophthora nicotianae (syn. $=P$. parasitica) and Phytophthora capsici are economically important soilborne plant pathogens with wide host ranges (1). Diseases caused by these pathogens, such as damping-off, root rot, blight, and fruit rot, may limit production of several important crops $(6,28)$. These Phytophthora spp. are capable of surviving in the soil for long periods of time in the absence of host plants and when weather conditions are not favorable for disease initiation and development (6). Thus, the main strategies used by growers to reduce losses due to these pathogens, especially at the early stages of plant development, are preplant soil fumigation with methyl bromide and postplant application of fungicides.

The implication of methyl bromide as an ozone depleting substance has prompted a search for alternatives for use in the control of soilborne plant pathogens. Soil solarization has been used in areas with arid climates for the management of soilborne diseases of high-value crops $(2,12,14$, $15,17,35)$. Soil solarization is a hydro-

Corresponding author: L. Coelho

E-mail: lisias@creta.ccr.ufsm.br

Florida Experiment Station Journal Series R06108 .

Accepted for publication 10 December 1998.

Publication no. D-1999-0119-02R

(C) 1999 The American Phytopathological Society thermal process in which moist soil is covered with transparent plastic and exposed to sunlight, allowing it to heat to temperatures that are lethal to many plant The effectiveness of solarization depends on soil color and structure, soil moisture, air temperature, length of day, and intensity of sunlight (38). Solarization has reduced populations of Fusarium spp. (2,16,33,37,38), Phytophthora spp. (2,12, 13,27,31,32,38), Pythium ultimum (7,9,21, $35,38,40,41)$, Verticillium dahliae $(10,12$, 16,33,35,38), and Rhizoctonia sp. (11,19, $23,35,38)$. However, disease management is not always observed following population suppression. For example, Stapleton and Garza-Lopez (41) reported a reduction in the population of Macrophomina phaseolina that did not result in less disease in the indicator crop. Other soilborne pathogens that have not been controlled by soil solarization include Fusarium oxysporum f. sp. radicis-lycopersici, Plasmodiophora brassicae, Pythium aphanidermatum, and Sclerotium rolfsii $(2,38)$.

Success of solarization for the control of plant diseases is closely associated with a combination of high ambient temperatures, maximum solar radiation, and optimum soil moisture $(14-17,38,39,41)$. Regions where high summer temperatures coincide with the rainy season, such as in the southeastern United States, may have less potential for successful solarization because the cooling effect of frequent rain showers and the extended cloud cover reduce the pathogens, insects, and weed seeds (38). solar radiation captured under the plastic tarp (2). Soil solarization has been used with varying degrees of success, however, in the southeastern United States to manage Rhizoctonia solani, Didymella bryoniae, Fusarium spp., and $P$. nicotianae $(2,19,20)$. Populations of $P$. nicotianae were reduced to undetectable levels in soil depths of up to $15 \mathrm{~cm}$ in three sites in North Florida; however, reduction in populations below $25 \mathrm{~cm}$ in depth was noted in only one site (2). In contrast, methyl bromide nearly eradicated the pathogen at depths of up to $35 \mathrm{~cm}$. Control of Fusarium spp. by soil solarization was limited to the top $5 \mathrm{~cm}$ of the soil, and no control was achieved at some sites (2). Keinath (19) found that the number of organic fragments colonized by $R$. solani was lower in solarized than in nonsolarized soils, but control of belly rot of pickling cucumber with solarization was not as effective as treatment with the fungicide chlorothalonil.

The type of plastic used for solarization may also influence soil solarization $(5,25,38)$. For example, thin polyethylene sheets $(25 \mu \mathrm{m})$ were more effective than thick sheets $(50$ to $100 \mu \mathrm{m})$ for the transmission of solar radiation to the soil (38), and a film of coextruded polyethylene plus ethylene vinyl acetate (thermoplast) was more effective than a clear low-density polyethylene film in raising soil temperatures and in trapping gases used for fumigation (25). Similarly, Chellemi et al. (3) found that a gas-impermeable film, consisting of a polyamide core sandwiched between two layers of polyethylene, was more effective than a coextruded, whiteon-black film for the reduction of populations of Paratrichodorus minor and Criconemella spp., and in the control of Fusarium wilt on tomatoes.

Soil solarization alone may not be consistently effective for the control of soilborne pathogens. In such cases, soil amendments have been used to enhance the performance of solarization $(9,20,37)$. Cruciferous residues, due to their high content of isothiocyanates and aldehydes (glucosinolate degradation products), have been suggested as amendments for use in combination with solarization (26). Cabbage leaf debris is the primary amendment that has been studied in combination with soil solarization $(20,37,38)$. 
Gamliel and Stapleton (8) characterized the antifungal volatiles from cabbage residue during solarization. The kinds of volatiles released from heated and nonheated soils differed, and the concentration of volatiles peaked during the first 2 weeks of of $S$. rolfsii failed to germinate after exposure to cabbage volatiles for 20 days. The use of a crucifer amendment associated with sublethal heating $\left(38^{\circ} \mathrm{C}\right)$ reduced germination of $P$. ultimum and $S$. rolfsii in vitro (40). It is possible that the major benefits of soil amendment with crucifer residues are associated with high but not lethal temperatures, when the heat alone is not sufficient to inactivate the pathogen; however, this aspect of the use of cabbage amendment has not been explored fully.

Cabbage amendments reduced populations of $F$. oxysporum f. sp. conglutinans; however, the association of solarization with the amendment was the most effective treatment for the control of this pathogen $(37,38)$. High concentrations of cabbage amendment had no effect on the subsequent cabbage crop, but phytotoxicity was observed when tomato seedlings were transplanted into the treated soil.

The objective of this study was to evaluate the effects of soil solarization and cabbage amendment on the survival of $P$. nicotianae and $P$. capsici under field conditions in North Florida.

\section{MATERIALS AND METHODS}

Solarization sites. In 1994, two sites were selected in commercial tomato production fields where control of soilborne pathogens had been achieved previously through the use of a preplant application of methyl bromide plus chloropicrin. Site 1 was in Decatur County, Georgia. Site 2 was in Gadsden County, Florida. In 1996, two experiments were conducted at the University of Florida North Florida Research and Educational Center in Gadsden County on soils that had been weed fallow for several years. Soil types at all locations were Orangeburg or Tifton loamy fine sands (siliceous, thermic), with $\mathrm{pH}$ values ranging from 5.0 to 6.6 (Table 1).

Inoculum production. Inoculum of $P$. nicotianae was produced in 250-ml flasks containing $20 \mathrm{~g}$ of wheat seeds and $30 \mathrm{ml}$ of deionized water (autoclaved twice at a 24-h interval). Four 5-mm agar plugs of actively growing mycelium of isolate $\mathrm{Pn} 21$ heating. Spores of $P$. ultimum and sclerotia

from a 4- to 7-day-old clarified V8 juice agar plate were transferred to each flask (30). The flasks were incubated at $25^{\circ} \mathrm{C}$ in the dark for 1 month and were shaken twice a week to ensure uniform growth of the isolate. Oospores of $P$. capsici were produced by inoculating similarly prepared 250-ml flasks of wheat seeds with three 5$\mathrm{mm}$ agar plugs of actively growing mycelium of each of two isolates of compatible mating types (Cp25 and Cp26). The flasks were incubated at $25^{\circ} \mathrm{C}$ in the dark for 2 months and shaken twice a week to encourage uniform growth of both isolates. Isolate Pn21 was originally obtained from periwinkle, and isolates $\mathrm{Cp} 25$ and $\mathrm{Cp} 26$ were obtained from watermelon in South Florida. All isolates are maintained in the collection of Phytophthora spp. of the Plant Pathology Department, University of Florida, Gainesville.

Inoculum of $P$. nicotianae or $P$. capsici was incorporated into the soil by mixing $200 \mathrm{mg}$ of shredded, infested wheat seeds with $3 \mathrm{~g}$ of soil. Nonpasteurized soils from sites 1 and 2 were used in 1994, and the soils were infested 2 days before the samples were taken to the field. To encourage augmented formation of chlamydospores or oospores in the two experiments in 1996, pasteurized soil from site 1 was infested with $P$. nicotianae and incubated at $18^{\circ} \mathrm{C}$ for 10 days, or with $P$. capsici and incubated at $25^{\circ} \mathrm{C}$ for 10 days, before its placement in the field tests. In all tests, each 3-g sample was enclosed in a $25 \mathrm{~cm}^{2}$ nylon envelope $(3-\mu \mathrm{m}$-pore size; Versapor 3000, Gelman Sciences, Inc., Ann Arbor, $\mathrm{MI}$ ), and the envelopes were buried in the soil at depths of 10 and $25 \mathrm{~cm}$ just before application of the solarization treatments.

Survival of the spores at the end of the solarization experiments was determined by plating infested soil from the envelopes on a medium selective for pythiaceous fungi (PARPH) (30).

Solarization experiments. At site 1, six treatments were arranged in a randomized complete block. Treatments were replicated four times and included a 30- $\mu \mathrm{m}$ thick, clear, gas-impermeable film (Bromotec film; Bromotec, Lawson Mardon Packaging, United Kingdom), a 30- $\mu$ mthick, coextruded white-on-black, lowdensity polyethylene (LDPE) film (whiteon-black film; Edison Plastics, Lee Hall, VA), and each film with or without cabbage residue (Brassica oleracea var. capi-

Table 1. Characteristics of field soils at the time of solarization

\begin{tabular}{lcccccc}
\hline Site & Year & pH & $\begin{array}{c}\text { Soil water } \\
\text { potentialy }(-\mathbf{k P a})\end{array}$ & $\begin{array}{c}\text { Organic } \\
\text { matter }(\boldsymbol{\%})\end{array}$ & $\begin{array}{c}\text { Sand-silt-clay } \\
(\mathbf{\%})\end{array}$ & Soil class \\
\hline 1 & 1994 & 6.6 & 5 & 1.1 & $84.0-6.0-10.0$ & Kandiudult $^{\mathrm{z}}$ \\
2 & 1994 & 5.1 & 15 & 0.5 & $88.5-4.5-7.0$ & Kandiudult $^{-1}$ \\
3, test 1 & 1996 & 5.0 & 5 & 1.0 & $80.4-11.1-8.5$ & Kandiudult \\
3, test 2 & 1996 & 5.0 & 50 & 1.2 & $82.8-10.0-7.2$ & Kandiudult \\
\hline
\end{tabular}

${ }^{\mathrm{y}}$ Estimated by the gravimetric method with oven drying, prior to initiation of the experiment, and transformed to matric potential.

${ }^{\mathrm{z}}$ Ultisol with profiles similar to paleudults but containing higher amounts of kaolinitic clay. tata L. cv. Constanza) incorporated into the soil at a rate of $8.0 \mathrm{~kg} / \mathrm{m}^{2}$. A tarped treatment (white-on-black film) fumigated with a 67:33 formulation of methyl bromide:chloropicrin at $39.2 \mathrm{~g} / \mathrm{m}^{2}$ and a nontarped treatment were used as controls.

At site 2, six treatments were arranged in a randomized complete block. Treatments included a 30- $\mu$ m-thick, clear, LDPE film (Polydak film, Polyon Barkai Ltd., Kibutz Barkai, Israel); the Bromotec film; each film with or without cabbage residue (cv. Constanza) incorporated into the soil at a rate of $6.6 \mathrm{~kg} / \mathrm{m}^{2}$; and the two controls.

For tests 1 and 2 at site 3 , six treatments were arranged in a randomized complete block design with four replicates. Treatments included the Bromotec film, the white-on-black film, each film with or without cabbage residue incorporated into the soil at a rate of $8.9 \mathrm{~kg} / \mathrm{m}^{2}$ for test 1 and $8.1 \mathrm{~kg} / \mathrm{m}^{2}$ for test 2 , and the two controls.

At sites 1 and 2, each replicate plot consisted of a single raised bed $(0.20 \times 0.90 \times$ $20 \mathrm{~m}$ ) prepared according to standard commercial production practices. Row orientation was north to south. Preplant fertilizer was broadcast into the beds at 212 $\mathrm{kg}$ of $\mathrm{N}, 65 \mathrm{~kg}$ of $\mathrm{P}$, and $212 \mathrm{~kg}$ of $\mathrm{K}$ per ha, and drip irrigation tubing was placed 5 $\mathrm{cm}$ beneath the soil on sites 1 and 2 prior to covering with plastic. At site 3 for tests 1 and 2, each replicate plot consisted of one raised $0.20 \times 0.90 \times 4.0 \mathrm{~m}$ bed prepared according to standard commercial production practices; row orientation was north to south. No fertilizer was applied and no irrigation tubing was placed on the beds.

Cabbage was grown and harvested in the plots at sites 1 and 2, and the residue was spread over the plots on 23 and 24 May 1994. Beds were prepared, the nylon envelopes containing the inoculum were placed in the soil, and the fumigant and plastic were applied on 3 June 1994 at site 1. Solarization was terminated on 22 July 1994, after 49 days, and the nylon envelopes were removed for determination of survival. At site 2, beds were prepared, the nylon envelopes containing the inoculum were buried, and the fumigant and plastic were applied on 15 June 1994; solarization was terminated on 2 August 1994, after 48 days, and the nylon envelopes were removed. For tests 1 and 2 at site 3, cabbage was harvested from a commercial field in Hastings, Florida; head and wrapper leaves were shredded and spread over the plots on 12 June for test 1, and on 19 June 1996 for test 2. Beds were prepared, two sets of nylon envelopes containing the inoculum were placed in each plot, and the fumigant and plastic were applied on 21 June and 28 June 1996, respectively. Solarization was terminated with the removal of the last nylon envelopes on 6 and 13 August 1996, after 45 days, for tests 1 and 2 , respectively.

Daily ambient temperature data were 
obtained from a weather station at the North Florida Research and Educational Center, in Quincy, located approximately $25 \mathrm{~km}$ from sites 1 and 2, while daily precipitation amounts were recorded at each site. In 1994, soil temperatures were monitored in site 2 at depths of 10 and 25 $\mathrm{cm}$ using thermocouple sensors connected to an electronic data logger (Omnidata International, Logan, UT). For the two tests at site 3, daily rainfall and ambient temperature data were recorded at the site. In 1996, temperature changes were monitored in test 1 at 10 - and $25-\mathrm{cm}$ depths in the soil using thermocouple sensors connected to an electronic data logger (Campbell Scientific, Logan, UT). Temperature data were compared with the thresholds of 41,44 , and $47^{\circ} \mathrm{C}$, as determined by Coelho (4). The first two thresholds $\left(41\right.$ and $\left.44^{\circ} \mathrm{C}\right)$ represent average temperatures reached at a depth of $10 \mathrm{~cm}$ in soils under solarization; the last one $\left(47^{\circ} \mathrm{C}\right)$ represents the optimum temperature for solarization in North Florida.

Statistical analysis. Survival data for each pathogen were log-transformed $[\ln (\mathrm{ppg}+1)]$ prior to analysis. Analysis of variance was performed with a repeatedmeasures procedure from SAS (SAS Institute, Cary, NC) release 6.11 for personal computers. Survival of $P$. nicotianae or $P$. capsici under each treatment was compared using Tukey's honestly significant difference procedure.

\section{RESULTS}

Environmental conditions. Environmental conditions varied from year to year (Fig. 1). The 1994 season was characterized by above-average precipitation and below-average temperatures. In 1996, precipitation was below average and temperatures were near 30-year averages. Soil moisture at the beginning of the solarization treatments varied with experiment, ranging from -5 to $-50 \mathrm{kPa}$ (Table 1). Precipitation occurred on $61 \%$ of the days of the solarization period at site $1,65 \%$ of the days at site $2,42 \%$ of the days in test 1 at site 3 , and $47 \%$ of the days in test 2 at site 3 (Table 2).

During the 48 days of solarization at site 2 , temperatures exceeded $41^{\circ} \mathrm{C}$ on 2 days at the $10-\mathrm{cm}$ soil depth in the nontarped treatment; $41^{\circ} \mathrm{C}$ was exceeded on 15 days in the Polydak film treatment and on 20 days in the Bromotec film treatment (Table $3)$. Temperatures exceeded $44^{\circ} \mathrm{C}$ at the 10 $\mathrm{cm}$ depth on 9 days under the Polydak film and on 13 days under the Bromotec film. Temperatures were above $47^{\circ} \mathrm{C}$ for 1 day and 3 days under the Polydak and the Bromotec films, respectively. At the $25-\mathrm{cm}$

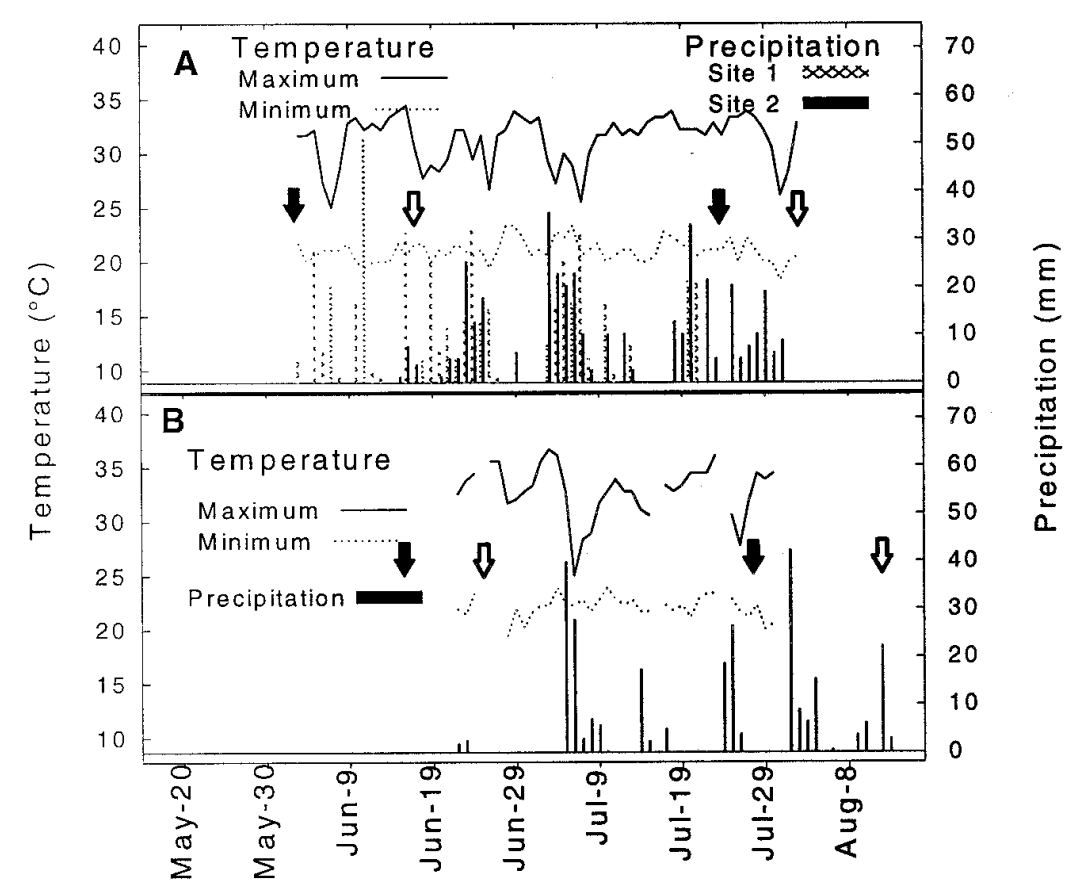

Fig. 1. Maximum and minimum air temperature and precipitation recorded at each site during the solarization period, from 1994 and 1996. (A) Solid arrows indicate beginning and end of solarization at site 1; open arrows indicate beginning and end of solarization at site 2. (B) Solid arrows indicate beginning and end of solarization in test 1 at site 3; open arrows indicate beginning and end of solarization in test 2 at site 3 .

Table 2. Environmental conditions during solarization periods

\begin{tabular}{lccccc}
\hline & & & \multicolumn{3}{c}{ Number of days } \\
\cline { 4 - 6 } Site & Year & $\begin{array}{c}\text { Precipitation } \\
(\mathbf{m m})\end{array}$ & $\begin{array}{c}\text { Solarization } \\
\text { period }\end{array}$ & $\begin{array}{c}\text { Precipitation } \\
\text { occurred }\end{array}$ & $\begin{array}{c}\text { Ambient } \\
\text { temperature } \geq \mathbf{3 5}^{\circ} \mathbf{C}\end{array}$ \\
\hline 1 & 1994 & 460 & 49 & 30 & 0 \\
2 & 1994 & 384 & 48 & 31 & 0 \\
3 , test 1 & 1996 & 232 & 45 & 19 & 6 \\
3 , test 2 & 1996 & 264 & 45 & 21 & 4 \\
\hline
\end{tabular}

Table 3. Temperature profiles during soil solarization at site 2 and at site 3 , test 1

\begin{tabular}{|c|c|c|c|c|c|c|c|c|c|c|c|c|c|}
\hline \multirow[b]{2}{*}{ Site ${ }^{w} /$ test } & \multirow{2}{*}{$\begin{array}{c}\text { Depth } \\
(\mathbf{c m})\end{array}$} & \multicolumn{3}{|c|}{ Nontarped $^{\mathrm{x}}$} & \multicolumn{3}{|c|}{ White-on-black } & \multicolumn{3}{|c|}{ Polydak film } & \multicolumn{3}{|c|}{ Bromotec film } \\
\hline & & $41^{\circ} \mathrm{C}$ & $44^{\circ} \mathrm{C}$ & $47^{\circ} \mathrm{C}$ & $41^{\circ} \mathrm{C}$ & $44^{\circ} \mathrm{C}$ & $47^{\circ} \mathrm{C}$ & $41^{\circ} \mathrm{C}$ & $\mathbf{4 4}^{\circ} \mathrm{C}$ & $47^{\circ} \mathrm{C}$ & $41^{\circ} \mathrm{C}$ & $44^{\circ} \mathrm{C}$ & $47^{\circ} \mathrm{C}$ \\
\hline \multicolumn{14}{|c|}{ Number of days above threshold } \\
\hline \multirow[t]{2}{*}{ Site 2} & 10 & 2 & 0 & 0 & $\mathrm{NT}^{\mathrm{y}}$ & NT & NT & $15^{\mathrm{z}}$ & 9 & 1 & 20 & 13 & 3 \\
\hline & 25 & 0 & 0 & 0 & NT & NT & NT & 0 & 0 & 0 & 0 & 0 & 0 \\
\hline \multirow{2}{*}{ Site $3 / 1$} & 10 & 1 & 0 & 0 & 0 & 0 & 0 & NT & NT & NT & 32 & 24 & 10 \\
\hline & 25 & 0 & 0 & 0 & 0 & 0 & 0 & NT & NT & NT & 1 & 0 & 0 \\
\hline \multicolumn{14}{|c|}{ Number of hours above threshold } \\
\hline \multirow[t]{2}{*}{ Site 2} & 10 & 4 & 0 & 0 & NT & NT & NT & 63 & 25 & 2 & 82 & 42 & 7 \\
\hline & 25 & 0 & 0 & 0 & NT & NT & NT & 0 & 0 & 0 & 0 & 0 & 0 \\
\hline \multirow[t]{2}{*}{ Site $3 / 1$} & 10 & 1 & 0 & 0 & 0 & 0 & 0 & NT & NT & NT & 225 & 125 & 24 \\
\hline & 25 & 0 & 0 & 0 & 0 & 0 & 0 & NT & NT & NT & 4 & 0 & 0 \\
\hline
\end{tabular}

${ }^{\mathrm{w}}$ Site 2 was solarized for 48 days in 1994; site 3 was solarized for 45 days in test 1 .

$\times$ Nontarped $=$ untreated soil; white-on-black $=30-\mu \mathrm{m}$-thick, coextruded white-on-black, LDPE film; Polydak film $=30-\mu \mathrm{m}-$ thick, clear, LDPE film; Bromotec film $=30-\mu \mathrm{m}$-thick, clear, gas-impermeable film.

${ }^{y} \mathrm{NT}=$ not tested.

${ }^{\mathrm{z}}$ Temperatures measured during the first 42 days of solarization. 
depth, temperatures never reached the $41^{\circ} \mathrm{C}$ threshold under any of the treatments. Maximum temperatures attained in site 2 at the $10-\mathrm{cm}$ depth under nontarped soil, the Polydak film, and the Bromotec film were $41.5,47.3$, and $48.5^{\circ} \mathrm{C}$, respectively. At the $25-\mathrm{cm}$ depth, maximum temperatures were $34.6,37.9$, and $38^{\circ} \mathrm{C}$ under nontarped soil, the Polydak film, and the Bromotec film, respectively. The mean soil temperature change during the day is illustrated in Figure 2A and B.

During the 45 days of solarization at site 3 for test 1, maximum temperatures attained at the $10-\mathrm{cm}$ depth under nontarped soil, white-on-black film, and the Bromotec film were $41.1,39.0$, and $49.1^{\circ} \mathrm{C}$, respectively. At the $25-\mathrm{cm}$ depth, maximum temperatures were $37.4,37.5$, and $41.4^{\circ} \mathrm{C}$ under nontarped soil, white-onblack film, and the Bromotec film, respectively. Under the Bromotec film, at the 10$\mathrm{cm}$ depth, maximum temperature was above $41^{\circ} \mathrm{C}$ for 32 days, above $44^{\circ} \mathrm{C}$ for 24 days, and above $47^{\circ} \mathrm{C}$ for 10 days; while at the $25-\mathrm{cm}$ depth, $41^{\circ} \mathrm{C}$ was exceeded on only 1 day (Table 3 ). Temperatures at the $10-\mathrm{cm}$ depth in the nontarped treatment exceeded $41^{\circ} \mathrm{C}$ on 1 day during the solarization period, and under the white-on-

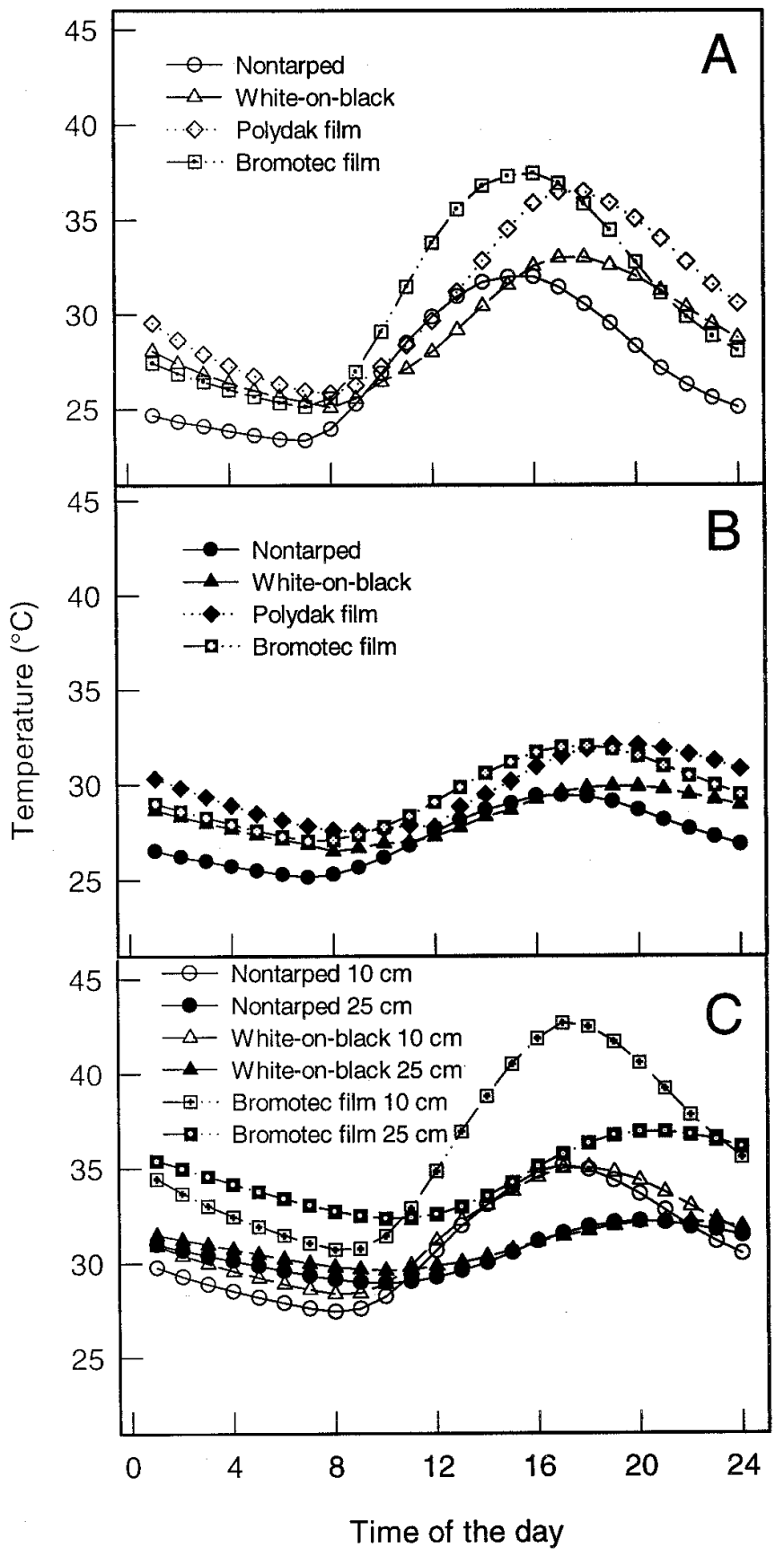

Fig. 2. Average hourly temperatures at 10 and $25 \mathrm{~cm}$ deep during the solarization period. Temperatures were measured in the untreated soil (nontarped), under the white-on-black, low density polyethylene film (white-on-black), under the Polydak film, and under the Bromotec film. (A) site 2 at the 10-cm depth (1994). (B) site 2 at the 25-cm depth. (C) site 3, test 1 (1996). black film, temperatures never reached that threshold. The mean temperature change during the day is illustrated in Figure 2C. Soil temperature changes for test 2 at site 3 were not monitored.

At the 10-cm depth, the highest accumulation of hours in which soil temperatures were greater than 41,44 , and $47^{\circ} \mathrm{C}$ was observed in test 1 at site 3 (Table 3 ). The lowest accumulation of hours was observed at site 2 . At site 2 , it was possible to compare the accumulation of hours above the given thresholds under the various solarization films. Under the Bromotec film at the $10-\mathrm{cm}$ depth, temperatures were above 41,44 , and $47^{\circ} \mathrm{C}$ for 82,42 , and $7 \mathrm{~h}$, respectively; while under the Polydak film the accumulation was of 63,25 , and $2 \mathrm{~h}$, respectively. In the nontarped treatment and at the $25-\mathrm{cm}$ depth of all treatments, temperatures never reached the $44^{\circ} \mathrm{C}$ threshold.

Survival of Phytophthora nicotianae. At site 1, propagules of $P$. nicotianae were not recovered from the nontarped or the methyl bromide treatments. Propagules were also not recovered at the $10-\mathrm{cm}$ depth in the Bromotec treatment, with or without cabbage, after 49 days of solarization (Table 4). The highest level of survival was observed under the white-on-black polyethylene film at $10 \mathrm{~cm}$ of depth with or without cabbage amendment. At the $25-\mathrm{cm}$ depth under the Bromotec film, propagules were recovered at the same levels as in the white-on-black film treatment.

At site 2, contaminants from the soil limited recovery of $P$. nicotianae in all treatments, except under the Polydak film at the 10-cm depth (data not shown).

Propagules of $P$. nicotianae were recovered from all treatments in test 1 at site 3 , except from soil treated with methyl bromide; however, there were no significant differences among the treatments (Table 4).

Trends similar to those observed in site 1 were observed in test 2 at site 3 (Table 4). Only methyl bromide eliminated the pathogen from the soil. The Bromotec film was the next best treatment at the $10-\mathrm{cm}$ depth, regardless of the cabbage amendment, for reduction of the population of the pathogen; however, at the $25-\mathrm{cm}$ depth, the Bromotec film was not effective, and more than 200 propagules of $P$. nicotianae survived per $g$ of soil. Similar results were observed under the white-on-black film, with or without cabbage amendment, and in the nontarped treatment. Survival in the nontarped treatments in tests 1 and 2, in contrast to the lack of survival in site 1, could have been due to the change in the procedure for soil infestation from that used for site 1; chlamydospores were already present at the beginning of the experiments in the soil prepared for tests 1 and 2, but not for site 1 (4).

Samples removed after 17 days of solarization in tests 1 and 2 at site 3 demonstrated that the pathogen survived for a 
short duration, except in the methyl bromide treatment (Table 4). Increases in populations were observed in test 2 , mostly at the $25-\mathrm{cm}$ depth, in the nontarped, Bromotec and white-on-black treatments after 45 days of solarization. Significant differences were observed at the $10-\mathrm{cm}$ depth between the two sampling dates under the Bromotec film; the population of $P$. nicotianae dropped to levels comparable to those in the methyl bromide treatment at the end of the solarization period.

Survival of Phytophthora capsici. At site 1, propagules were not recovered at the $10-\mathrm{cm}$ depth after treatment with methyl bromide, the Bromotec film, or the Bromotec film combined with cabbage (Table $5)$. Low levels of survival at the $25-\mathrm{cm}$ depth under the methyl bromide treatment, the Bromotec film, and the Bromotec film combined with cabbage were obtained, but the levels were not different from the same treatments at the $10-\mathrm{cm}$ depth. Greatest survival was observed under the white-onblack film at the $10-\mathrm{cm}$ depth, regardless of cabbage amendment, and in the nontarped treatment.

At site 2, survival was significantly reduced, in comparison to the nontarped treatments, with methyl bromide, Bromotec film, and Polydak film with or without cabbage at $10 \mathrm{~cm}$, and with Bromotec film plus cabbage at $25 \mathrm{~cm}$ (Table 5).

\section{DISCUSSION}

Soil solarization is a pasteurization process dependent on solar energy to heat the soil and kill pathogens. Effective pasteurization occurs when soil sustains temperatures that are lethal to the fungal propagules infesting the soil, such as those reported in arid climates $(18,34,38)$. However, in climates where cloud cover and rainfall interrupt the heating process of the soil, maximum temperatures recorded tend to be lower, and control of soilborne plant pathogens is not as effective $(2,3,19,29)$.

Temperature changes were monitored in two of the four experiments (site 2; and site 3 , test 1 ). Inferences from site to site have to be made with caution, since soil color, proportion of sand, silt, and clay content, and soil moisture were different. Each of these factors can affect the temperature accumulation in soil, and when taken together could cause significant deviations in temperature from the patterns observed at the site where temperatures were actually measured. Because tests 1 and 2 at site 3 were only a few meters apart, with the same type of soil, any differences in temperature could be explained best by the change in moisture content. As shown by Mahrer et al. (24), the higher the water content of the soil, the higher the maximum temperature. Thus, higher survival of the pathogens in test 2 could be explained by the lower moisture content of the soil.

$P$. nicotianae is believed to survive in root fragments and organic matter in the soil, or as chlamydospores free in the soil (6). Infested wheat seeds were selected for inoculum to favor the formation of chlamydospores in soil, simulating natural spore formation for field survival. Soil moisture also may have contributed to the variability in recovery of $P$. nicotianae among tests and sites. In test 1 at site 3 , the plastic treatments were laid down after a week of frequent rains, with soil moisture

Table 5. Survival of Phytophthora capsici in the soil

\begin{tabular}{lccc}
\hline & $\begin{array}{c}\text { Depth } \\
\text { (cm) }\end{array}$ & \multicolumn{2}{c}{ Propagules per g of soil } \\
\cline { 3 - 4 } Treatment $^{\mathbf{w}}$ & 10 & Site $\mathbf{~}$ & Site 2 \\
\hline Bromotec film & 25 & $0.0^{\mathrm{x}} \mathrm{a}^{\mathrm{y}}$ & $0.0 \mathrm{a}$ \\
Bromotec film & $1.5 \mathrm{ab}$ & $7.0 \mathrm{ab}$ \\
Bromotec film + cabbage & 10 & $0.0 \mathrm{a}$ & $0.4 \mathrm{a}$ \\
Bromotec film + cabbage & 25 & $1.2 \mathrm{ab}$ & $0.5 \mathrm{a}$ \\
Polydak film & 10 & $\mathrm{NT}$ & $0.0 \mathrm{a}$ \\
Polydak film & 25 & $\mathrm{NT}$ & $11.2 \mathrm{ab}$ \\
Polydak film + cabbage & 10 & $\mathrm{NT}$ & $0.2 \mathrm{a}$ \\
Polydak film + cabbage & 25 & $\mathrm{NT}$ & $7.9 \mathrm{ab}$ \\
White-on-black & 10 & $84.6 \mathrm{c}$ & $\mathrm{NT}$ \\
White-on-black & 25 & $77.4 \mathrm{c}$ & $\mathrm{NT}$ \\
White-on-black + cabbage & 10 & $16.3 \mathrm{c} \mathrm{cc}$ & $\mathrm{NT}$ \\
White-on-black + cabbage & 25 & $0.0 \mathrm{a}$ & $\mathrm{NT}$ \\
Methyl bromide & 10 & $1.1 \mathrm{ab}$ & $0.2 \mathrm{a}$ \\
Methyl bromide & 25 & $33.4 \mathrm{c}$ & $0.9 \mathrm{a}$ \\
Nontarped & 10 & $63.0 \mathrm{c}$ & $33.9 \mathrm{~b}$ \\
Nontarped & 25 & $25.6 \mathrm{~b}$
\end{tabular}

${ }^{\mathrm{w}}$ Nontarped $=$ untreated soil; methyl bromide $=$ soil fumigated with methyl bromide:chloropicrin at $39.2 \mathrm{~g} / \mathrm{m}^{2}$; white-on-black = soil solarized under a 30- $\mu \mathrm{m}$-thick, coextruded white-on-black, LDPE film; Polydak film = soil solarized under a 30- $\mu$ m-thick, clear, LDPE film; Bromotec film $=30-\mu \mathrm{m}-$ thick, clear, gas-impermeable plastic film. Soil was either nonamended or amended with cabbage $(+$ cabbage) at 8.0 and $6.8 \mathrm{~kg} / \mathrm{m}^{2}$ at sites 1 and 2 , respectively.

$\mathrm{x}$ Weighted means $([\exp \{$ mean $\}]-1)$.

y Main effect means followed by the same letter do not differ according to Tukey's honestly significant difference procedure $(P \leq 0.05)$; data were transformed to $\ln (\mathrm{ppg}+1)$ prior to analysis.

z NT $=$ not tested.

Table 4. Survival of Phytophthora nicotianae in the soil

\begin{tabular}{|c|c|c|c|c|c|c|}
\hline \multirow[b]{3}{*}{ Treatment $^{x}$} & \multirow{3}{*}{$\begin{array}{c}\text { Depth } \\
(\mathrm{cm})\end{array}$} & \multicolumn{5}{|c|}{ Propagules/g of soil } \\
\hline & & \multirow{2}{*}{$\begin{array}{c}\text { Site } 1 \\
49 \text { days }\end{array}$} & \multicolumn{2}{|c|}{ Site 3 - test 1} & \multicolumn{2}{|c|}{ Site 3 - test 2} \\
\hline & & & 17 days & 45 days & 17 days & 45 days \\
\hline Bromotec film & 10 & $0.0^{\mathrm{y}} \mathrm{a}^{\mathrm{z}}$ & $2.0 \mathrm{a}$ & $0.4 \mathrm{a}$ & 544.6 b & $4.4 \mathrm{a}$ \\
\hline Bromotec film & 25 & $39.1 \mathrm{abc}$ & $4.1 \mathrm{a}$ & $2.1 \mathrm{a}$ & $168.0 \mathrm{~b}$ & $202.3 \mathrm{~b}$ \\
\hline Bromotec film + cabbage & 10 & $0.0 \mathrm{a}$ & $2.7 \mathrm{a}$ & $0.9 \mathrm{a}$ & $52.5 \mathrm{~b}$ & $1.0 \mathrm{a}$ \\
\hline Bromotec film + cabbage & 25 & $7.2 \mathrm{ab}$ & $0.7 \mathrm{a}$ & $2.3 \mathrm{a}$ & $491.3 \mathrm{~b}$ & $362.0 \mathrm{~b}$ \\
\hline White-on-black & 10 & $380.5 \mathrm{c}$ & $22.8 \mathrm{a}$ & $4.0 \mathrm{a}$ & $196.6 \mathrm{~b}$ & $733.9 \mathrm{~b}$ \\
\hline White-on-black & 25 & $12.9 \mathrm{abc}$ & $16.3 \mathrm{a}$ & $0.9 \mathrm{a}$ & $186.4 \mathrm{~b}$ & $697.8 \mathrm{~b}$ \\
\hline White-on-black + cabbage & 10 & $439.1 \mathrm{c}$ & $101.9 \mathrm{a}$ & $14.8 \mathrm{a}$ & $830.5 \mathrm{~b}$ & $825.3 \mathrm{~b}$ \\
\hline White-on-black + cabbage & 25 & $44.9 \mathrm{bc}$ & $25.0 \mathrm{a}$ & $12.3 \mathrm{a}$ & $608.3 \mathrm{~b}$ & $749.5 \mathrm{~b}$ \\
\hline Methyl bromide & 10 & $0.0 \mathrm{a}$ & $0.0 \mathrm{a}$ & $0.0 \mathrm{a}$ & $0.0 \mathrm{a}$ & $0.0 \mathrm{a}$ \\
\hline Methyl bromide & 25 & $0.0 \mathrm{a}$ & $0.0 \mathrm{a}$ & $0.0 \mathrm{a}$ & $0.0 \mathrm{a}$ & $0.0 \mathrm{a}$ \\
\hline Nontarped & 10 & $0.0 \mathrm{a}$ & $21.6 \mathrm{a}$ & $14.9 \mathrm{a}$ & $1,138.7 \mathrm{~b}$ & $700.7 \mathrm{~b}$ \\
\hline Nontarped & 25 & $0.0 \mathrm{a}$ & $6.2 \mathrm{a}$ & $4.5 \mathrm{a}$ & $311.8 \mathrm{~b}$ & $687.3 \mathrm{~b}$ \\
\hline
\end{tabular}

${ }^{\mathrm{x}}$ Nontarped = untreated soil; methyl bromide = soil fumigated with methyl bromide:chloropicrin at $39.2 \mathrm{~g} / \mathrm{m}^{2}$; white-on-black = soil solarized under a 30 $\mu \mathrm{m}$-thick, coextruded white-on-black, LDPE film; Bromotec film = soil solarized under a 30- $\mu$ m-thick, clear, gas-impermeable plastic film. Soil was either nonamended or amended with cabbage (+ cabbage) at 80,89 , and 81 tons/ha at site 1 , and for tests 1 and 2 at site 3 , respectively.

y Weighted means $([\exp \{$ mean $\}]-1)$.

${ }^{z}$ Main effect means followed by the same letter do not differ according to Tukey's honestly significant difference procedure $(P \leq 0.05)$; data were transformed to $\ln (\mathrm{ppg}+1)$ prior to analysis. 
very uniform throughout the soil profile. In test 2 at site 3 , the week preceding the application of the plastic treatments was hot and dry, and irrigation was required to provide moisture for the solarization. These factors may have affected the results observed for the tests, especially in test 2 , where higher numbers of surviving propagules were observed at greater depths. Since the solarization process depends on soil moisture for heat conduction, it is possible that temperatures did not rise as much in test 2 as in test 1 due to the lack of moisture. Indeed, the water status in test 1 $(-5 \mathrm{kPa})$ was 10 times higher than that of test $2(-50 \mathrm{kPa})$.

The absence of chlamydospores in the wheat seeds at the time of inoculum preparation, as observed microscopically in a squash mount, and a subsequent lack of survival of $P$. nicotianae in the nontarped treatments in 1994 prompted a search for methods that would augment the production of this type of inoculum (4). The highest number of chlamydospores was observed in pasteurized soil from site 1 after incubation at $18^{\circ} \mathrm{C}$ for 10 days; thus, inoculum was prepared in 1996 by infesting microwaved soil from site 1 and incubating it at $18^{\circ} \mathrm{C}$ for 10 days before burial in all of the test sites. After this change in inoculum preparation, $P$. nicotianae was recovered from the nontarped treatment (Table 4).

Solarization with Polydak or Bromotec film was effective in reducing populations of $P$. nicotianae at the $10-\mathrm{cm}$ depth. At this depth, chlamydospore mortality was similar to that achieved by fumigation with methyl bromide. However, at the $25-\mathrm{cm}$ depth, the populations recovered on dilution plates were similar to those in the nontarped or the white-on-black film controls. Clearly, solarization alone, or solarization with cabbage amendments, cannot be relied upon to eliminate $P$. nicotianae from soil under the conditions encountered in these tests. Chellemi et al. (2) also found that soil solarization alone reduced populations of $P$. nicotianae to undetectable levels at a depth of $15 \mathrm{~cm}$; however, at the $25-\mathrm{cm}$ depth, no differences in survival were observed between the solarized and the control treatments in two sites.

Although the same two isolates of $P$. capsici were used in all crosses to produce oospores for all tests, the numbers of oospores observed in wheat seeds were not consistent from year to year. The evaluation of survival of $P$. capsici also was hindered by the poor germination of propagules in the selective medium. Larkin et al. (22) compared different media for the germination of oospores of $P$. capsici and found that PARPH was the best medium for the study of this pathogen. However, in the present study, only approximately $1 \%$ of the oospores germinated in PARPH. Even with the low populations detected, $P$. capsici survived better in the nontarped treatments and under the white-on-black film, regardless of the cabbage amendment. Control of this pathogen was most effective with methyl bromide, followed by the Bromotec and Polydak films at the 10-cm depth.

The failure of cabbage to affect the survival of either pathogen is contrary to observations of other researchers $(20,37,38)$. It is probable that the differences observed are due either to amounts of amendment used or to the preparation of the cabbage amendment and its incorporation into the soil. For all of the field plots in the present study, cabbage was either chopped with a machete (1994) or shredded in a shredder (1996). In either case, the fragments were relatively large, and incorporation was done by disking the residue into the soil at the same time that the raised beds were being prepared, which may have led to an uneven distribution of the amendment in the soil profile. In contrast, Ramirez-Villapudua and Munnecke (37) used air-dried cabbage ground with a Wiley mill to a fine powder. This residue was incorporated into small amounts of soil, which were placed in plastic bags to be solarized. Further work by these authors (36) indicated that populations of F. oxysporum f. sp. conglutinans were reduced by the incorporation of cabbage into the soil at rates that were higher than those used in the experiments reported here. Keinath (20) found that gummy stem blight of watermelon was reduced in areas that received cabbage amendment and solarization; however, no information about the amount of residue incorporated into the soil was given. It also may be that the effectiveness of cabbage as a soil amendment is influenced by the drying process, and during the experiments reported here, rainfall during the drying time may have had a detrimental effect.

Although increased efficacy of soil solarization by cabbage amendment on the reduction of populations of $P$. nicotianae and $P$. capsici was observed, these reductions were not enough to eliminate the pathogens at the same depths as methyl bromide. Therefore, other alternatives to enhance the efficacy of soil solarization in North Florida must be found.

\section{ACKNOWLEDGMENTS}

The first author was supported by $\mathrm{CNPq}$ (Conselho Nacional de Pesquisa e Desenvolvimento, Brazil). This research was supported, in part, by the Gadsden County Tomato Growers Association and the United States Department of Agriculture, Specific Cooperative Agreement 586617-4-019. We thank N. T. Gargiulo and John Allen Smith for the use of their tomato production fields.

\section{LITERATURE CITED}

1. Alfieri, S. A., Jr., Langdon, K. R., Kimbrough, K. R., El-Gholl, N. E., and Wehlburg, C. 1994. Diseases and Disorders of Plants in Florida. Bull. 14. Division of Plant Industry, Fla. Dep. Agric. Cons. Serv.

2. Chellemi, D. O., Olson, S. M., and Mitchell, D. J. 1994. Effects of soil solarization and fumigation on survival of soilborne pathogens of tomato in northern Florida. Plant Dis. 78:1167-1172.

3. Chellemi, D. O., Olson, S. M., Mitchell, D. J., Secker, I., and McSorley, R. 1997. Adaptation of soil solarization to the integrated management of soilborne pests of tomato under humid conditions. Phytopathology 87:250-258.

4. Coelho, L. 1997. Reduction of populations of Phytophthora spp. with soil solarization under field conditions and thermal inactivation of Phytophthora nicotianae. Ph.D. diss. University of Florida, Gainesville.

5. DeVay, J. E. 1991. Use of soil solarization for control of fungal and bacterial plant pathogens including biocontrol. Pages 79-93 in Soil Solarization. J. E. DeVay, J. J. Stapleton, and C. L. Elmore, eds. FAO Plant Prot. Prod. Pap. 109

6. Erwin, D. C., and Ribeiro, O. K. 1996. Phytophthora Diseases Worldwide. American Phytopathological Society, St. Paul, MN.

7. Gamliel, A., Hadar, E., and Katan, J. 1989. Soil solarization to improve yield of Gypsophila in monoculture systems. Acta Hortic 255:131-138.

8. Gamliel, A., and Stapleton, J. J. 1993. Characterization of antifungal volatile compounds evolved from solarized soil amended with cabbage residues. Phytopathology 83:899905.

9. Gamliel, A., and Stapleton, J. J. 1993. Effect of chicken compost or ammonium phosphate and solarization on pathogen control, rhizosphere microorganisms, and lettuce growth. Plant Dis. 77:886-891.

10. Ghini, R., Bettiol, W., Spadotto, C. A., Moraes, G. J., Paraiba, L. C., and Mineiro, J. L. C. 1993. Soil solarization for the control of tomato and eggplant Verticillium wilt and its effect on weed and micro-arthropod communities. Summa Phytopathol. 19:183-189.

11. Grooshevoy, S. E., Khudyna, I. P., and Popova, A. A. 1941. Methods for disinfecting seed-bed soil by natural sources of heat. Rev. Appl. Mycol. 20:87-88.

12. Hartz, T. K., DeVay, J. E., and Elmore, C. L. 1993. Solarization is an effective soil disinfestation technique for strawberry production. HortScience 28:104-106.

13. Juarez-Palacios, C., Felix-Gastelum, R. Wakeman, R. J., Paplomatas, E. J., and DeVay, J. E. 1991. Thermal sensitivity of three species of Phytophthora and the effect of soil solarization on their survival. Plant Dis. 75:1160-1164.

14. Katan, J. 1980. Solar pasteurization of soils for disease control: Status and prospects. Plant Dis. 64:450-454.

15. Katan, J. 1981. Solar heating (solarization) of soil for control of soilborne pests. Annu. Rev. Phytopathol. 19:211-236.

16. Katan, J., Greenberger, A., Alon, H., and Grinstein, A. 1976. Solar heating by polyethylene mulching for the control of diseases caused by soil-borne pathogens. Phytopathology 66:683-688.

17. Katan, J., Grinstein, A., Greenberger, A., Yarden, O., and DeVay, J. E. 1987. The first decade (1976-1986) of soil solarization (solar heating): A chronological bibliography. Phytoparasitica 15:229-255.

18. Katan, J., Rotem, I., Finkel, Y., and Daniel, J. 1980. Solar heating of the soil for the control of pink root and other soilborne diseases in onions. Phytoparasitica 8:39-50.

19. Keinath, A. P. 1995. Reductions in inoculum density of Rhizoctonia solani and control of belly rot on pickling cucumber with solarization. Plant Dis. 79:1213-1219.

20. Keinath, A. P. 1996. Soil amendment with cabbage residue and crop rotation to reduce gummy stem blight and increase growth and yield of watermelon. Plant Dis. 80:564-570. 
21. Kulkarni, R. N., Kalra, A., and Ravindra, N. S. 1992. Integration of soil solarization with host resistance in the control of dieback and collar and root rot diseases of periwinkle. Trop. Agric. 69:217-222.

22. Larkin, R. P., Ristaino, J. B., and Campbell, C. L. 1995. Detection and quantification of Phytophthora capsici in soil. Phytopathology 85:1057-1063.

23. Lewis, J. A., and Papavizas, G. C. 1974. Effect of volatiles from decomposing plant tissues on pigmentation, growth, and survival of Rhizoctonia solani. Soil Sci. 118:156-163.

24. Mahrer, Y., Naot, O., Rawitz, E., and Katan, J. 1984. Temperature and moisture regimes in soils mulched with transparent polyethylene. Soil Sci. Soc. Am. J. 48:362-367.

25. Malathrakis, N. E., and Loulakis, M. D. 1989. Effectiveness of the type of polyethylene sheet on soil solarization. Acta Hortic. 255:235-241.

26. Mayton, H. S., Olivier, C., Vaughn, S. F., and Loria, R. 1996. Correlation of fungicidal activity of Brassica species with allyl isothiocyanate production in macerated leaf tissue. Phytopathology 86:267-271.

27. McGovern, R. J., and Begeman, J. P. 1996. Reduction of Phytophthora blight of madagascar periwinkle in the landscape by soil solarization. Proc. Fla. State Hortic. Soc. 108:58-60.

28. McGovern, R. J., Jones, J. P., Mitchell, D. J.,
Pluim, R. A., and Gilreath, P. R. 1993. Severe outbreak of Phytophthora blight and fruit rot of cucurbits in Florida. (Abstr.) Phytopathology 83:1388.

29. McSorley, R., and Parrado, J. L. 1986. Application of soil solarization to rockdale soils in a subtropical environment. Nematropica 16:125-140.

30. Mitchell, D. J., and Kannwischer-Mitchell, M E. 1992. Phytophthora. Pages 31-38 in: Methods for Research on Soilborne Phytopathogenic Fungi. L. L. Singleton, J. D. Mihail, and C. M. Rush, eds. American Phytopathological Society, St. Paul, MN.

31. Moens, M., and Aicha, B. B. 1990. Control of pepper wilt in Tunisia. Parasitica 46:103-109.

32. Pinkas, Y., Kariv, A., and Katan, J. 1984. Soil solarization for the control of Phytophthora cinnamomi: Thermal and biological effects. (Abstr.) Phytopathology 74:796.

33. Porter, I. J., and Merriman, P. R. 1985. Evaluation of soil solarization for control of root diseases of row crops in Victoria. Plant Pathol. 34:108-118

34. Pullman, G. S., DeVay, J. E., Garber, R. H., and Weinhold, A. R. 1979. Control of soilborne fungal pathogens by plastic tarping of soil. Pages 431-438 in: Soil-borne Plant Pathogens. B. Schippers and W. Gams, eds. Academic Press, New York.

35. Pullman, G. S., DeVay, J. E., Garber, R. H. and Weinhold, A. R. 1981. Soil solarization:
Effects on Verticillium wilt of cotton and soilborne populations of Verticillium dahliae Pythium spp., Rhizoctonia solani, and Thie laviopsis basicola. Phytopathology 71:954959.

36. Ramirez-Villapudua, J., and Munnecke, D. E. 1987. Control of cabbage yellows (Fusarium oxysporum f. sp. conglutinans) by solar heating of field soils amended with dry cabbage residues. Plant Dis. 71:217-221.

37. Ramirez-Villapudua, J., and Munnecke, D. E. 1988. Effect of solar heating and soil amendments of cruciferous residues on Fusarium oxysporum f. sp. conglutinans and other organisms. Phytopathology 78:289-295.

38. Souza, N. L. 1994. Solarização do solo. Summa Phytopathol. 20:3-15.

39. Stapleton, J. J., and DeVay, J. E. 1984. Thermal components of soil solarization as related to changes in soil and root microflora and in creased plant growth response. Phytopathology 74:255-259.

40. Stapleton, J. J., Duncan, R. A., and Thomassian, C. 1995. Antifungal activity of certain cruciferous amendments when combined with soil heating for biofumigation. (Abstr.) Phytopathology 85:1042.

41. Stapleton, J. J., and Garza-Lopez, J. G. 1988 Mulching of soils with transparent (solarization) and black polyethylene films to increase growth of annual and perennial crop in southwestern Mexico. Trop. Agric. 65:29-33. 